\title{
Analisis Dan Perancangan Sistem Pengisian Kartu Rencana Study (KRS) Untuk Jurusan Teknik Informatika Dan Sistem Informasi Kampus Tanri Abeng University
}

\author{
Desty Septiani ${ }^{1}$, Pramitha Dwi Larasati ${ }^{2}$, Ari $\operatorname{Irawan}^{3}$
}

\begin{abstract}
Tanri Abeng University (TAU) sangat berupaya untuk membuat sebuah terobosan baru, terutama dalam teknologi digital yang mempermudah mahasiswa serta tenaga pengajar dalam melakukan kewajibannya masing-masing, seperti misalnya pengisian Kartu Rencana Studi (KRS) bagi mahasiswa. Menyadari banyak kesulitan yang muncul dalam pengisian KRS secara manual, saat ini banyak universitas yang telah menerapkan sistem registrasi mata kuliah (KRS) secara online. Penelitian ini dilakukan dengan melakukan observasi dan studi pustaka dalam melakukan analisis perencanaan. Pengembangan system dilakukan dengan menggunakan Model SDLC (System Development Life Cycle). Menggunakan UML (Unified Model Language) serta Netbeans sebagai tools. Hasil dari penelitian ini berupa sistem KRS online untuk TAU.
\end{abstract}

Kata Kunci: KRS, KRS Online, System Development Life Cycle, Unified Model Language, Netbeans

\section{PENDAHULUAN}

Universitas Tanri Abeng atau Tanri Abeng University (disingkat TAU) merupakan salah satu perguruan tinggi swasta di Indonesia yang didirikan oleh pengusaha dan mantan Menteri Negara Pendayagunaan BUMN pada Kabinet Pembangunan VII dan Kabinet Reformasi Pembangunan, Tanri Abeng pada 7 Maret 2011 atas dasar kepedulian untuk membangun bangsa. Kurikulum TAU menekankan pada pencapaian kedalaman ilmu dan keterampilan dengan tetap berpegang pada kurikulum yang dirancang dengan

Received: 5 Februari 2018; Revised: 1 Maret 2018; Accepted: 1 April 2018

D. Septiani, Teknik Informatika, School of Engineering and Technology Universitas Tanri Abeng (desty_s@student.tau.ac.id)

P.D. Larasati, Sistem Informasi, School of Engineering and Technology Universitas Tanri Abeng (pramitha.dwi@tau.ac.id)

A. Irawan, Sistem Informasi, School of Engineering and Technology Universitas Tanri Abeng (ari_irawan@tau.ac.id)

http://journal.uinjkt.ac.id/index.php/aism menggunakan standar nasional dan internasional yang disesuaikan dengan peraturan yang ada di Indonesia.

TAU sangat berupaya untuk membuat sebuah terobosan baru, baik dari segi pembelajaran ataupun media pembelajarannya. Teknologi amat sangat diutamakan terutama teknologi digital yang mempermudah mahasiswa serta tenaga pengajar dalam melakukan kewajibannya masing-masing, seperti misalnya pengisian Kartu Rencana Studi (KRS) bagi mahasiswa.

KRS adalah istilah yang diperuntukkan bagi proses registrasi mata kuliah yang harus dilakukan oleh mahasiswa. Dalam proses KRS ini mahasiswa harus memilih mata kuliah yang akan diambilnya, beserta kelas dan jadwalnya berdasarkan daftar mata kuliah dengan jadwal dan kelas yang dibuka. Pemilihan dan penyusunan mata kuliah yang dipilih beserta jadwal dan kelasnya ini biasanya dilakukan seminggu sebelum proses pengisian KRS dapat dilakukan. Namun ada juga mata kuliah yang telah dipaketkan tergantung pada kebijakan masing-masing universitas.

Pada pelaksanaannya, proses KRS ini banyak menimbulkan kesulitan, terutama bagi mahasiswa yang melakukan pengisian KRS secara manual. Tentu saja hal ini membuat proses pengisian KRS menjadi suatu hal yang memerlukan perjuangan ekstra berat dari mahasiwa yang melakukan pengisian KRS. Menyadari banyak kesulitan yang muncul dalam pengisian KRS secara manual, saat ini banyak universitas yang telah menerapkan sistem registrasi mata kuliah (KRS) secara online.

Sistem KRS online tidak jauh berbeda dengan sistem KRS manual, hanya saja pengisian KRS dilakukan secara online dengan memanfaatkan teknologi, terutama teknologi internet yang saat ini sedang berkembang. Sebagian besar universitas yang menerapkan sistem KRS online menggunakan aplikasi yang berbasiskan Web, yaitu dengan pengaksesan website. Namun ada pula universitas yang telah menerapkan pengisian KRS online dengan aplikasi. TAU adalah salah satu universitas yang juga mengharuskan mahasiswanya untuk melakukan proses registrasi mata kuliah (KRS) dan Tanri Abneg University akan mulai menerapkan sistem KRS secara online. 


\section{LANDASAN TEORI}

Pada bagian ini, landasan teori dalam penelitian ini dijabarkan.

\subsection{Sistem Informasi}

Sistem adalah kumpulan dari elemen-elemen yang berinteraksi untuk mencapai suatu tujuan tertentu. sistem ini menggambarkan suatu kejadian-kejadian dan kesatuan yang nyata adalah suatu objek nyata, seperti tempat, benda, dan orang-orang yang betul-betul ada dan terjadi [1]. Suatu sistem mempunyai karakteristik atau sifat-sifat tertentu, yaitu mempunyai komponen-komponen (components), batas sistem (boundary), lingkungan luar (environments), penghubung (interface), masukan (input), keluaran (output), pengolah (process), dan sasaran (objectives) atau tujuan (goal) [1].

Informasi merupakan data yang telah diproses sedemikian rupa sehingga meningkatkan pengetahuan seseorang yang menggunakan data tersebut. Informasi adalah data yang telah diolah menjadi sebuah bentuk yang berarti bagi penerimanya dan bermanfaat dalam pengambilan keputusan saat ini atau saat mendatang [2]. Analisis sistem adalah penguraian suatu sistem informasi yang utuh ke dalam bagian-bagian, komponennya dengan maksud untuk mengidentifikasikan dan mengevaluasi permasalahan-permasalahan, kesempatankesempatan, hambatan-hambatan yang terjadi serta kebutuhan- kebutuhan yang diharapkan sihingga dapat diusulkan perbaikkan-perbaikan [1]. Perancangan sistem adalah suatu kegiatan merancang dan menentukan bagaimana cara mengolah sistem informasi dari hasil analisis sistem sehingga dapat memenuhi kebutuhan dari pengguna (user) termasuk data, perancangan user interface dan aktivitas proses [5].

\subsection{Basis Data}

Basis data (database) merupakan suatu pengorganisasian sekumpulan data yang saling terkait sehingga memudahkan aktivitas untuk memperoleh informasi. Untuk mengolah basis data diperlukan perangkat lunak yang disebut Database Management System (DBMS). DBMS adalah perangkat lunak sistem yang memungkinkan para pemakai membuat, memelihara, mengontrol dan mengakses basis data dengan cara yang praktis dan efesien. DBMS dapat digunakan untuk mengakomodasikan berbagai macam pemakai yang memiliki kebutuhan akses yang berbeda-beda [2].

\subsection{Unified Model Language}

Unified Model Language (UML) adalah salah satu alat bantu yang sangat handal di dunia pengembangan sistem yang berorientasi obyek. Hal ini di sebabkan karena UML menyediakan bahasa pemodelan visual yang memungkinkan bagi pengembang sistem untuk membuat cetak biru atas visi mereka dalam bentuk yang baku, mudah di mengerti, serta di lengkapi dengan mekanisme yang efektif untuk berbagi (sharing) dan mengkomunikasikan rancangan mereka dengan yang lain [3].

UML mendefinisikan diagram-diagram berikut ini [6]:

a. Use case Diagram

Use case diagram menggambarkan fungsionalitas yang diharapkan dari sebuah sistem. Yang ditekankan adalah "apa" yang diperbuat sistem, dan bukan "bagaimana". Sebuah use case merepresentasikan sebuah interaksi antara actor dengan sistem. Gambar 1, merupakan notasi dari Use case diagram.

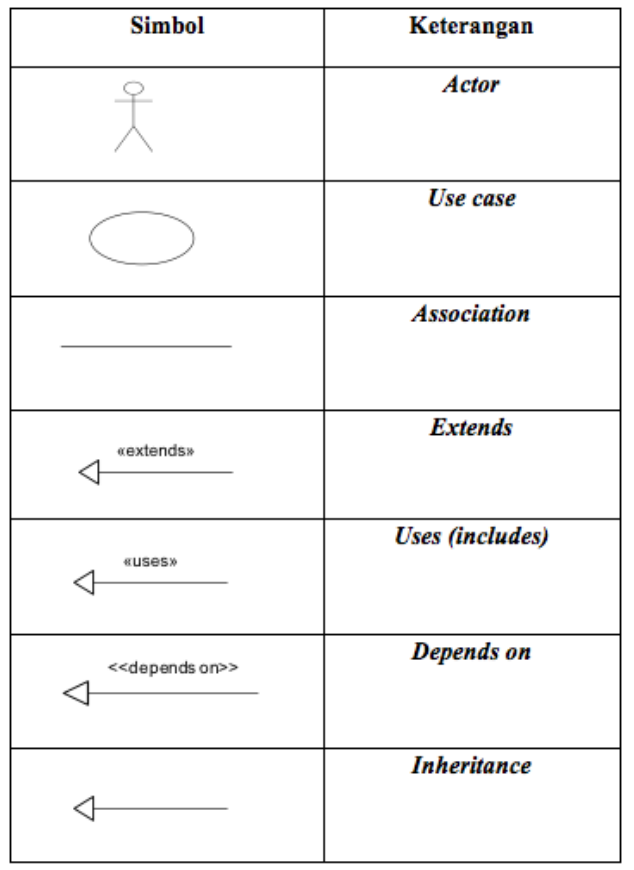

Gambar 1. Notasi Use Case Diagram

b.

\begin{tabular}{|c|l|}
\hline Simbol & \multicolumn{1}{|c|}{ Keterangan } \\
\hline & Class \\
\hline & 1. class name \\
\hline & 2. attributes \\
\hline & Association! \\
\hline & \\
\hline & \\
\hline & Agregation \\
\hline & \\
\hline
\end{tabular}

Gambar 2. Notasi Class Diagram

Class menggambarkan keadaan (atribut atau properti) suatu sistem, sekaligus menawarkan layanan untuk memanipulasi keadaan tersebut (metoda atau fungsi). Class diagram menggambarkan struktur dan deskripsi class, package dan objek beserta hubungan satu sama lain seperti containment, pewarisan, asosiasi, dan lain-lain. Sebuah class diagram terdiri dari sejumlah kelas yang dihubungkan dengan garis yang menunjukkan hubungan antar kelas yang disebut dengan Associations. Adapun gambar 2 menunjukkan notasi dari class diagram. 


\section{c. Activity Diagram}

Activity diagram menggambarkan berbagai alir aktivitas dalam sistem yang sedang dirancang, bagaimana masingmasing alir berawal, decision yang mungkin terjadi, dan bagaimana mereka berakhir. Activity diagram juga dapat menggambarkan proses paralel yang mungkin terjadi pada beberapa eksekusi. Gambar 3, menunjukkan notasi dari activity diagram.

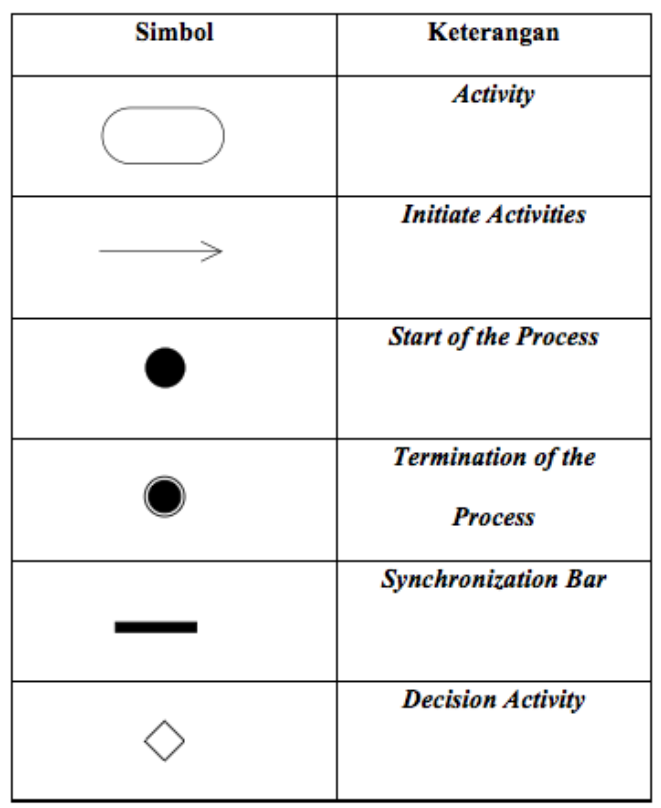

Gambar 3. Notasi Activity Diagram

\subsection{SQL dan Netbeans}

$S Q L$ yang merupakan singkatan dari Structured Query Language merupakan bahasa yang paling standar yang digunakan untuk menyimpan dan menerima data dari dan kedalam sebuah database. SQL digunakan didalam sistem database seperti MySQL, Oracle, PortgreSQLm Sybase dan Microsoft SQL Server. Didalam SQL terdapat standar ANSI dan sistem Database seperti MYSQL yang mengimplementasikan standar tersebut [7].

NetBeans adalah Integrated Development Environment (IDE) berbasiskan Jawa dari Sun Microsystems yang berjalan di atas Swing. Swing sebuah teknologi Jawa untuk pengembangan aplikasi Desktop yang dapat bejalan di berbagai macam platforms seperti Windows, Linux,MacOS X and Solaris [4].

\section{METODOLOGI PENELITIAN}

\section{PEMBAHASAN}

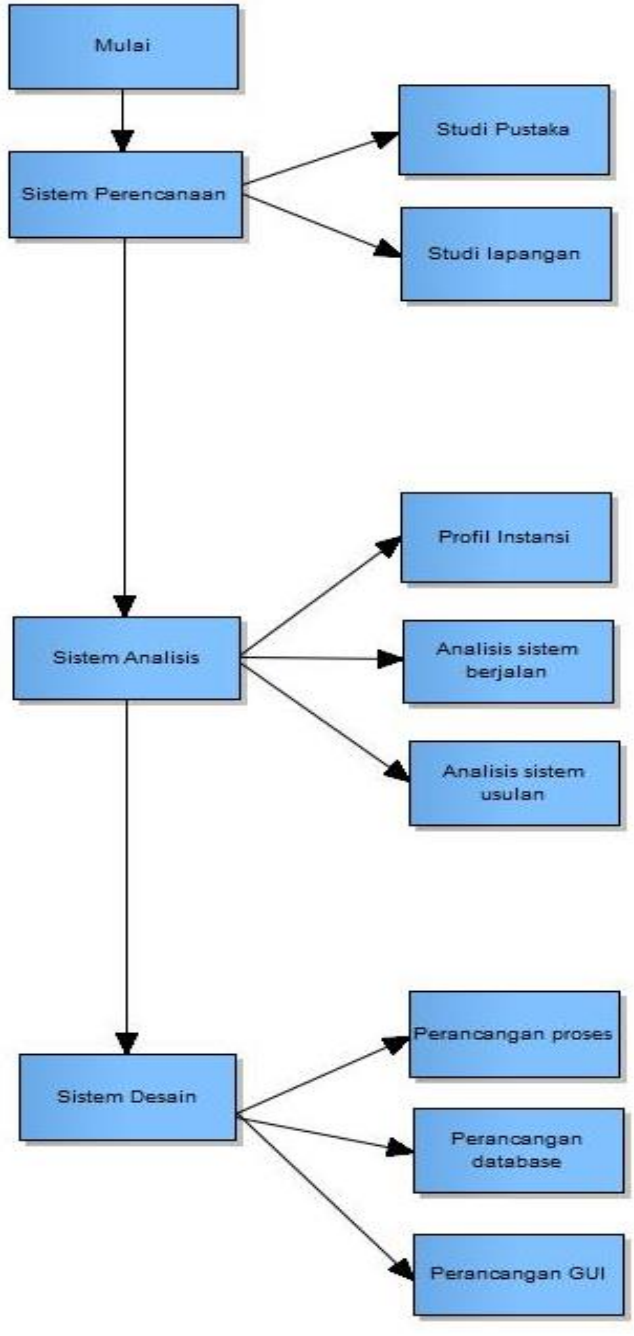

Gambar 4. Kerangka Penelitian

Bagian ini menjelaskan kerangka penelitian yang ditunjukkan oleh gambar 4. Adapun penelitian ini dilakukan dalam 4 tahapan, (1) permulaan pelaksanaan penelitian, (2) melakukan sistem perencanaan sebagai langkah untuk pengumpulan data dengan cara studi pustaka dan studi lapangan untuk mendapatkan informasi mengenai kebutuhan sistem, (3) sistem analisis dengan menjabarkan profil instansi, menjabarkan sistem berjalan dalam instansi dan menjabarkan sistem usulan untuk instansi, dan (4) dilakukannya desain sistem. Tahap keempat ini dilakukan dengan melakukan perancangan proses terlebih dahulu yaitu membuat use case diagram, dan activity diagram menggunakan UML (Unified Model Language), dilanjutkan dengan merancang database dan yang terakhir adalah perancangan GUI (Graphic User Interface) menggunakan Netbeans. Desain sistem dalam penelitian ini adalah menggunakan model SDLC (system Development Life Cycle). 


\subsection{Sistem Analisis}

\subsubsection{Analisis Sistem Berjalan}

Berdasarkan dari observasi di lapangan, diperoleh alur sistem berjalan dalam proses pengisian KRS mahasiswa di TAU. Hasil dari analisis sistem berjalan ditunjukkan dalam gambar 2 .

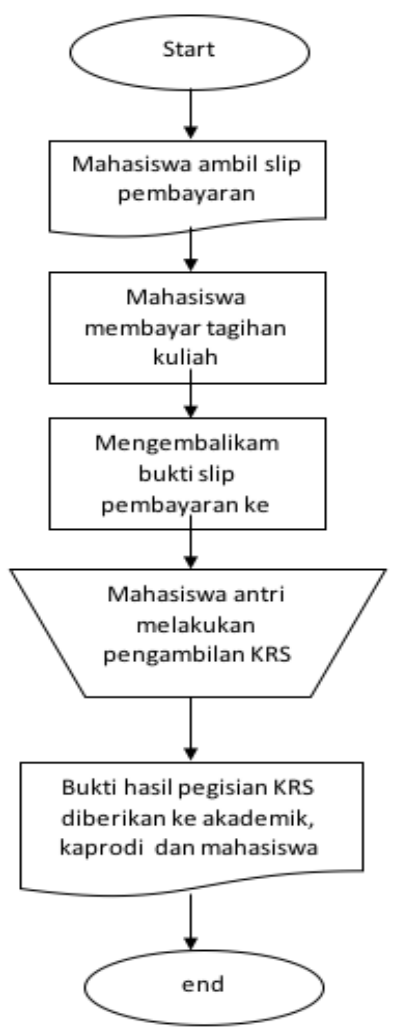

Gambar 5. Sistem Berjalan

Sistem berjalan pada gambar 5 merupakan hasil analisis berdasarkan paper-based form pengajuan, persertujuan dan pengisian KRS secara manual di TAU. Adapun gambar 6 menggambarkan paper-based form KRS.

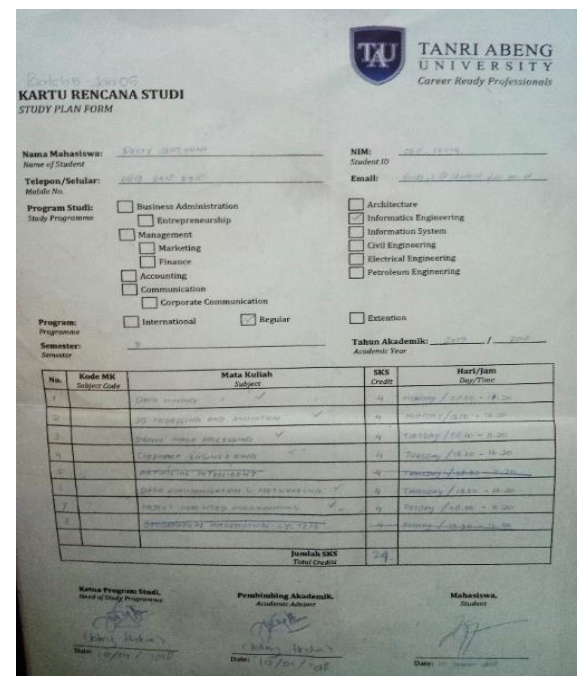

Gambar 6. Paper-based form KRS

\subsubsection{Analisis Sistem Usulan}

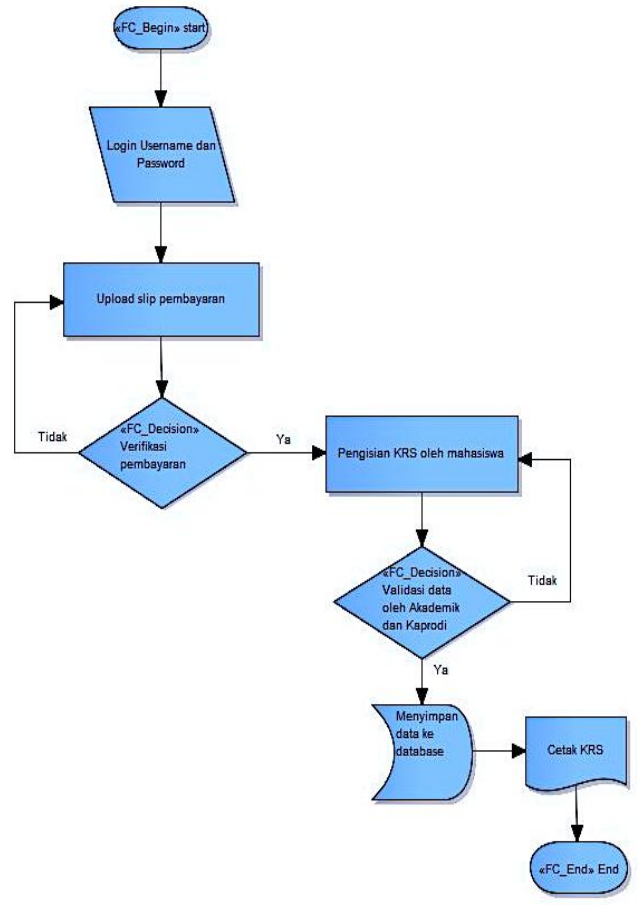

Gambar 7. Analisis Sistem Usulan

Selanjutnya setelah didapati sistem berjalan, adalah menetukkan usulan sistem yang digunakan. Usulan sistem ini digunakan untuk mendesain suatu sistem yang akan dibuat. Perancangan sistem usulan dalam penelitian ini dilakukan berdasarkan proses analisis terhadap sistem berjalan dengan perkembangan teknologi yang akan diajukan. Analisis sistem usulan ditunjukkan pada gambar 7 .

\subsection{Sistem Desain}

4.2.1 Perancangan Proses

a. Use Case Diagram

Use case bekerja dengan cara mendeskripsikan tipikal interaksi antara user (pengguna) sebuah sistem dengan sistemnya sendiri melalui sebuah cerita bagaimana sebuah sistem di pakai.

- Identifikasi Aktor

Tahap ini dilakukan untuk mengidentifikasi aktor yang terlibat dalam sistem seperti yang ditunjukkan dalam tabel 1 .

Tabel 1. Identifikasi Aktor

\begin{tabular}{cclc}
\hline \hline No & Actor & \multicolumn{2}{c}{ Description } \\
\hline 1 & Akademik & Menginput semua data \\
& / admin & keperluan perkuliahan, \\
& & serta melakukan validasi \\
& & terhadapa data yang \\
& & diteruskan (KRS) oleh \\
& & mahasiswa \\
& & Melihat, dan melakukan \\
2 & Dosen & & pengecekan terhadap data \\
& & yang di teruskan (KRS) \\
& & oleh mahasiswa \\
& & Melihat daftar mata \\
3 & mahasiswa dan melakukan \\
\hline \hline
\end{tabular}

http://journal.uinjkt.ac.id/index.php/aism 


input untuk pengisian
KRS

- Identifikasi Use Case

Tahap ini dilakukan untuk mengidentifikasi proses yang digunakan atau proses yang terjadi dalam sistem seperti yang ditunjukkan dalam tabel 2.

Tabel 2. Identifikasi Use Case

\begin{tabular}{|c|c|c|c|}
\hline No & $\begin{array}{l}\text { Use Case } \\
\text { Name }\end{array}$ & Description & Actor \\
\hline 1 & $\begin{array}{l}\text { Login dan } \\
\text { logout }\end{array}$ & $\begin{array}{l}\text { Use case ini } \\
\text { menggambarkan } \\
\text { proses input } \\
\text { data username } \\
\text { dan password } \\
\text { untuk dapat } \\
\text { masuk kedalam } \\
\text { system dan } \\
\text { keluar sistem }\end{array}$ & $\begin{array}{l}\text { Akademik/ } \\
\text { admin } \\
\text { Dosen } \\
\text { mahasiswa }\end{array}$ \\
\hline 2 & $\begin{array}{l}\text { Melihat } \\
\text { data profil }\end{array}$ & $\begin{array}{l}\text { Use case ini } \\
\text { menggambarkan } \\
\text { proses melihat } \\
\text { profil dari user }\end{array}$ & $\begin{array}{l}\text { Akademik/ } \\
\text { admin } \\
\text { Dosen } \\
\text { mahasiswa }\end{array}$ \\
\hline 3 & $\begin{array}{l}\text { Melakukan } \\
\text { pengisian } \\
\text { kartu } \\
\text { rencana } \\
\text { studi }\end{array}$ & $\begin{array}{l}\text { Use case ini } \\
\text { menggambarkan } \\
\text { proses input } \\
\text { data mata kuliah } \\
\text { yang akan di } \\
\text { ambil/diikuti } \\
\text { oleh mahasiswa }\end{array}$ & mahasiswa \\
\hline 4 & $\begin{array}{l}\text { Membuat } \\
\text { data user / } \\
\text { register }\end{array}$ & $\begin{array}{l}\text { Use cae ini } \\
\text { menggambarkan } \\
\text { kegiatan input } \\
\text { data user }\end{array}$ & $\begin{array}{l}\text { Akademik } \\
\text { /admin }\end{array}$ \\
\hline 5 & $\begin{array}{l}\text { Cetak } \\
\text { KRS }\end{array}$ & $\begin{array}{l}\text { Use case ini } \\
\text { menggambarkan } \\
\text { cetak kartu } \\
\text { rencana studi } \\
\text { mahasiswa }\end{array}$ & mahasiswa \\
\hline
\end{tabular}

- Use Case Diagram

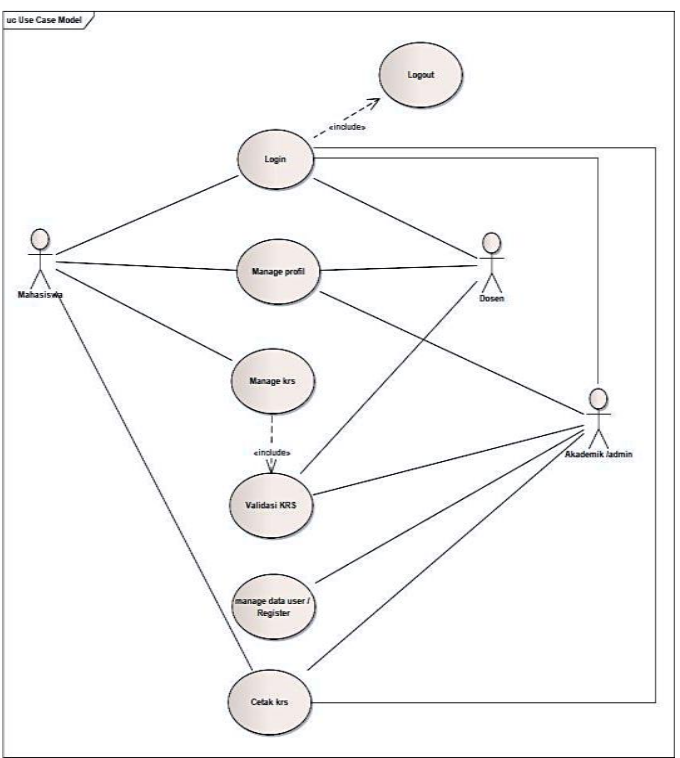

Gambar 8. Use Case Diagram

Gambar 8 di atas menunjukkan use case diagram pada penelitian ini. Adapun dalam gambar terdapat 3 aktor yaitu Mahasiswa, Dosen dan Akademik. Terdapat 7 proses dalam sistem diantaranya user dapat melakukan $\log$ in dan log out, dapat memanage profil serta cetak krs. Pada proses manage krs hanya dapat dilakukan oleh mahasiswa, sedangkan dosen dan akademik hanya dapat memvalidasi krs mahasiswa. Akademik disini berperan sebagai admin yang dapat melakukan registrasi user dan me-manage data user.

\section{b. Activity Diagram}

Activity diagram di bawah ini menunjukkan seluruh proses kegiatan yang dilakukan oleh user terhadap sistem sesuai dengan proses yang telah ditentukan dalam use case diagram sebelumnya. Adapun activity diagram pada penelitian ini terdiri dari 6 activity, antara lain :

(a) Activity Diagram Log In

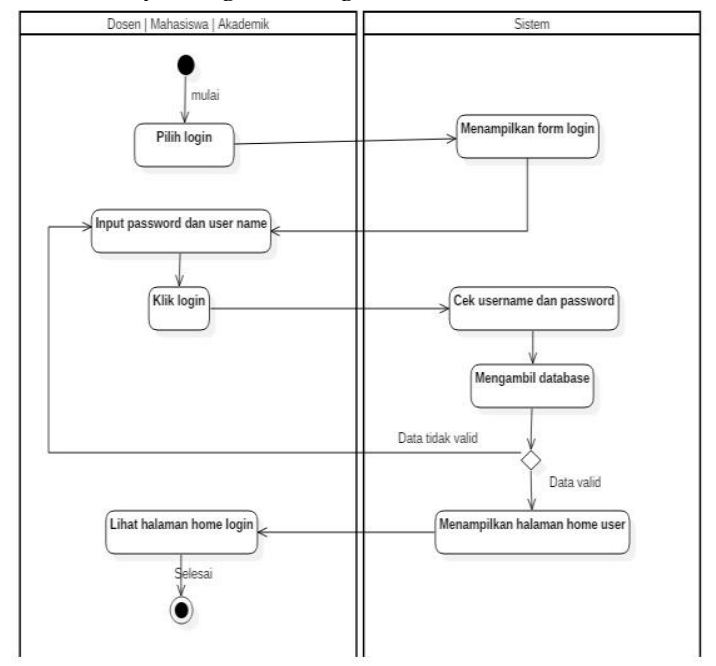


Gambar 9. Activity Diagram Log In

(b) Activity Diagram Log Out

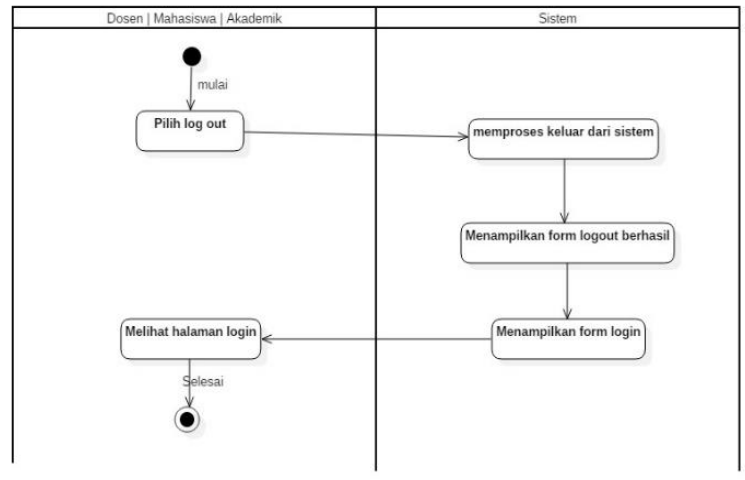

Gambar 10. Activity Diagram Log Out

(c) Activity Diagram Register

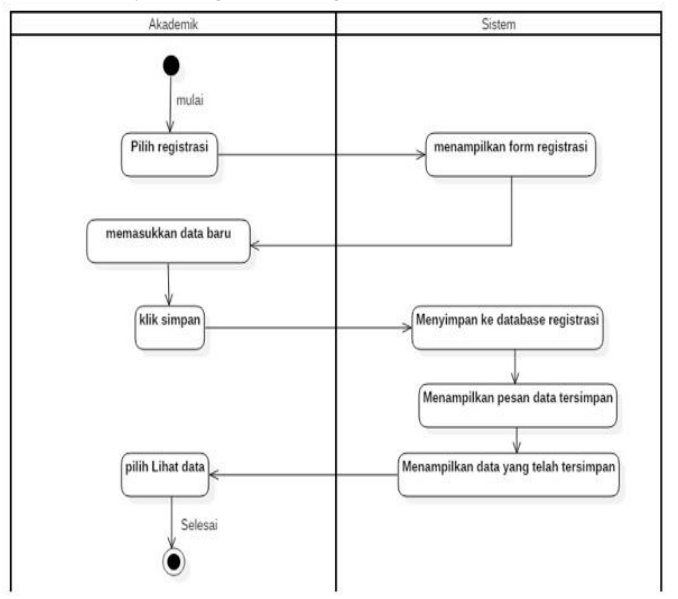

Gambar 11. Activity Diagram Register

(d) Activity Diagram Manage Profil

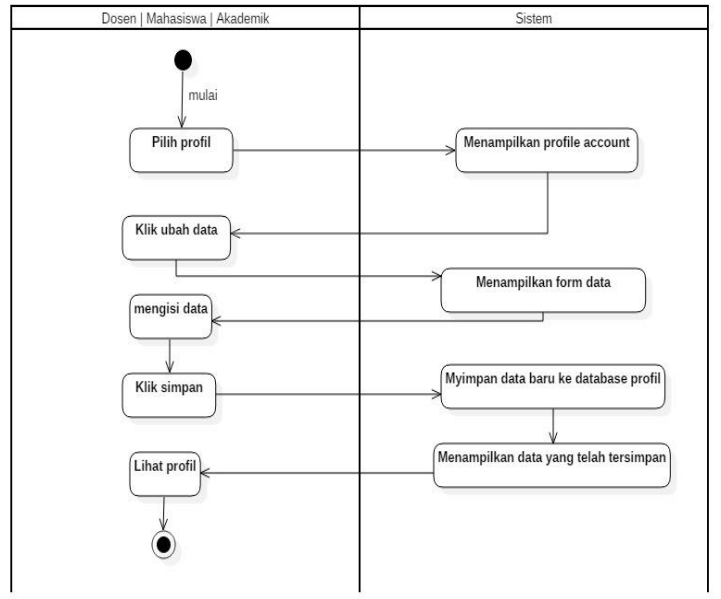

Gambar 12. Activity Diagram Manage Profil

(e) Activity Diagram Cetak

ttp://journal.uinjkt.ac.id/index.php/aism

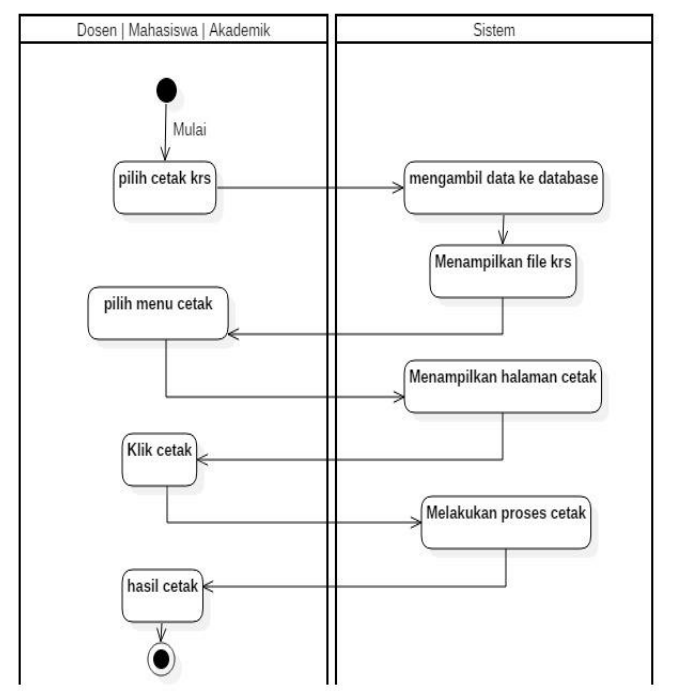

Gambar 13. Activity Diagram Cetak

(f) Activity Diagram Isi KRS

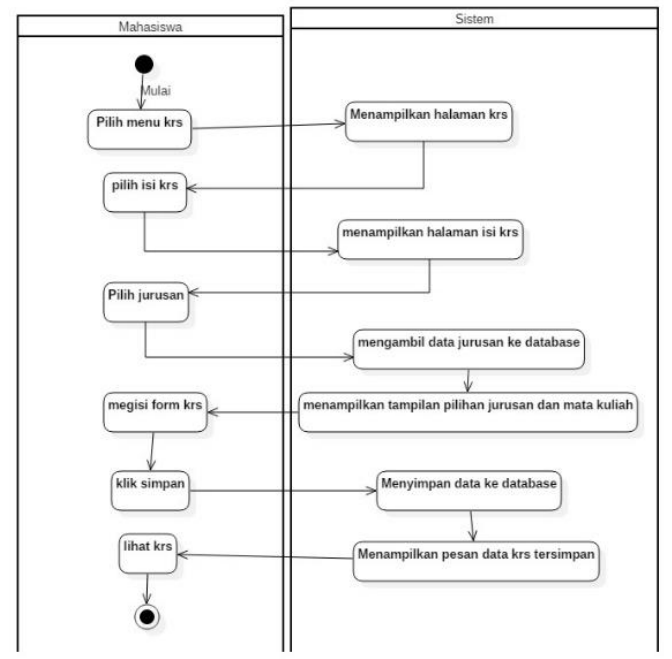

Gambar 14. Activity Diagram Cetak

\subsubsection{Perancangan Database}

Perancangan database dibuat dengan menentukan variabel-variabel yang digunakan dalam sistem. Adapun setiap variabel memiliki atribut masing-masing yang terdiri dari nama field dan tipe data, dalam penelitian ini dilakukan sebagai berikut;

a. Tabel mahasiswa

Variabel yang terdapat dalam rancangan database ini adalah variabel mahasiswa yang digunakan untuk menyimpan data mahasiswa secara keseluruhan. Tabel ini diambil berdasarkan data mahasiswa yang terdaftar di universitas dan merupakan data master. Adapun atribut-atribut dari variabel mahasiswa ditunjukkan dalam tabel 3.

Tabel 3. Tabel Mahasiswa

\begin{tabular}{|c|c|c|}
\hline $\mathrm{No}$ & Field & Tipe data \\
\hline 1 & nim & Int (12) \\
\hline 2 & Nama & $\operatorname{Varchar}(50)$ \\
\hline
\end{tabular}




\begin{tabular}{llc}
\hline \hline 3 & Jenis_kelamin & $\operatorname{Varchar}(20)$ \\
4 & Kode_prodi & $\operatorname{Varchar}(6)$ \\
5 & Prodi & $\operatorname{Varchar}(20)$ \\
6 & angkatan & $\operatorname{Varchar}(50)$ \\
7 & Pembimbing_akademik & $\operatorname{Varchar}(50)$ \\
\hline \hline
\end{tabular}

b. Tabel prodi

Tabel 4. Tabel prodi

\begin{tabular}{clc}
\hline \hline No & \multicolumn{1}{c}{ Field } & Tipe data \\
\hline 1 & Kode_prodi & Varchar(50) \\
2 & Program_prodi & Varchar(50) \\
3 & Ketua_prodi & Varchar(50) \\
\hline \hline
\end{tabular}

Tabel 4 merupakan atribut-atribut dari variabel yang terdapat dalam rancangan database yaitu variabel prodi yang digunakan untuk menyimpan data program studi yang terdapat dalam universitas secara keseluruhan. Tabel ini diambil berdasarkan data program studi yang terdaftar pada universitas dan merupakan data master.

\section{c. Tabel Mata_kuliah}

Variabel yang terdapat dalam rancangan database ini adalah variabel Mata_Kuliah yang digunakan untuk menyimpan data mata kuliah secara keseluruhan. Tabel ini diambil berdasarkan data mata kulian yang terdaftar pada universitas dan merupakan data master. Adapun atribut-atribut dari variabel mata_kuliah ditunjukkan dalam tabel 5 .

Tabel 5. Tabel mata_kuliah

\begin{tabular}{clc}
\hline \hline No & \multicolumn{1}{c}{ field } & Tipe data \\
\hline 1 & KodeMK & $\operatorname{Varchar}(10)$ \\
2 & mataKuliah & $\operatorname{Varchar(50)}$ \\
3 & SKS & $\operatorname{Int}(6)$ \\
\hline \hline
\end{tabular}

\section{d. Tabel Dosen}

Variabel yang terdapat dalam rancangan database ini adalah variabel dosen yang digunakan untuk menyimpan data dosen secara keseluruhan. Tabel ini diambil berdasarkan data dosen yang terdaftar pada universitas dan merupakan data master. Adapun atribut-atribut dari variabel dosen ditunjukkan dalam tabel 6 .

Tabel 6. Tabel Dosen

\begin{tabular}{clc}
\hline \hline No & \multicolumn{1}{c}{ Filed } & Tipe data \\
\hline 1 & nidn & $\operatorname{Int}(20)$ \\
2 & Nama_dosen & $\operatorname{Varchar}(50)$ \\
\hline \hline
\end{tabular}

\section{e. Tabel krs}

Variabel yang terdapat dalam rancangan database ini adalah variabel krs yang digunakan untuk menyimpan data perkuliahan yang diambil oleh mahasiswa secara keseluruhan. Tabel ini diambil berdasarkan data krs yang terdaftar pada universitas dan merupakan data transaksi. Adapun atributatribut dari variabel krs ditunjukkan dalam tabel 7 .

Tabel 7. Tabel krs

\begin{tabular}{clc}
\hline \hline No & \multicolumn{1}{c}{ Field } & Tipe data \\
\hline 1 & noKRS & $\operatorname{Varchar}(10)$ \\
2 & KodeMK & $\operatorname{Varchar(10)}$ \\
3 & SKS & $\operatorname{Int}(6)$ \\
4 & nidn & $\operatorname{Int}(20)$ \\
\hline \hline
\end{tabular}

\subsubsection{Perancangan GUI}

Berikut ini adalah perancangan tampilan (interface) Sistem Kartu Rencana Study (Krs) Untuk Jurusan Teknik Informatika dan Sistem Informasi Kampus Tanri Abeng University, yaitu ;

\section{a. Interface $\log$ In}

Dalam gambar 15, interface log in merupakan tampilan awal user untuk melakukan $\log$ in ke dalam sistem. Terdapat kolom username dan password serta tombol log in. User dapat melakukan "lupa password" jika password yang di masukkan salah dan atau lupa password.

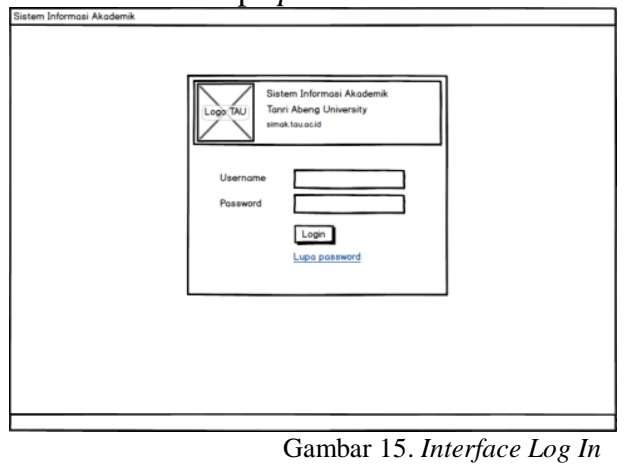

\section{b. Interface Home}

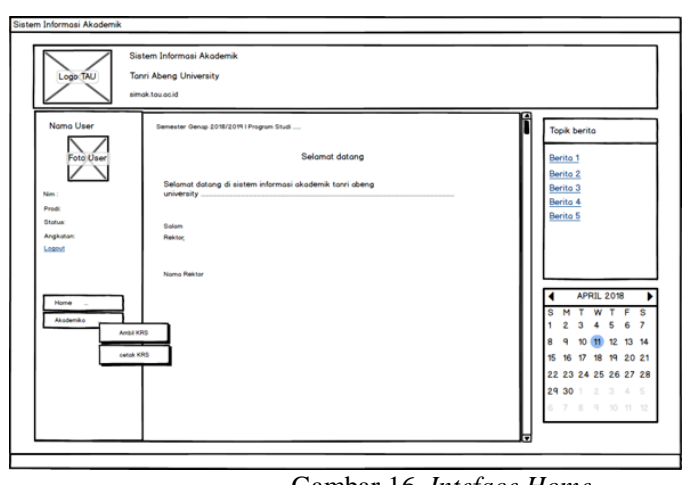

Dalam gambar 16 di atas, interface $\log$ in merupakan tampilan awal home untuk user yang telah melakukan log in ke dalam sistem. Pada sisi kiri, terdapat теnи akademik yang berisi sub-menu ambil krs dan cetak krs. Pada sisi sebelah 
kanan terdapat tampilan "topik Berita" yang berisi beritaberita terbaru mengenai krs serta tanggal kalender akademik.

\section{c. Interface Menu Ambil KRS}

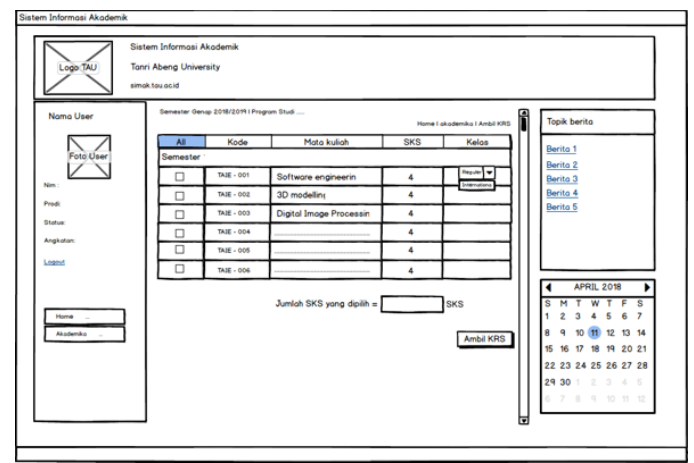

Gambar 17. Interface Menu Ambil KRS

Dalam gambar 17 di atas, interface log in merupakan tampilan pengambilan krs untuk user yang telah melakukan log in ke dalam sistem. Isi dalam halaman menu ini adalah daftar dari krs untuk mengambil krs yang dilakukan oleh mahasiwa. Terdapat pilihan kolom kode dan mata kuliah serta SKS dan kelas yang tersedia. Semua data rersebut akan sesuai dengan semester yang diampuh oleh mahasiswa.

\section{d. Interface Form KRS}

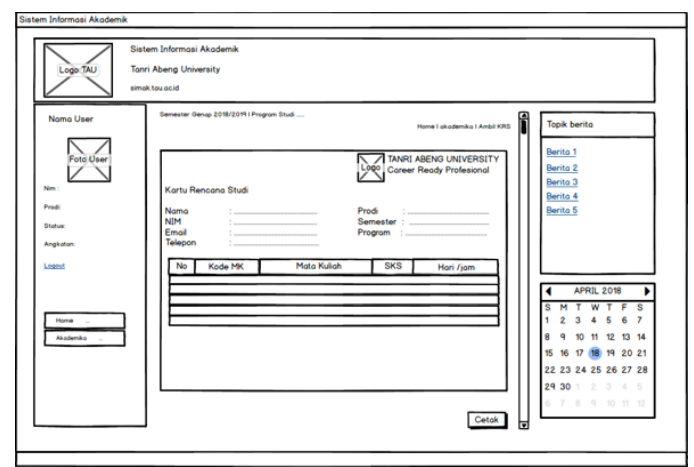

Gambar 18. Interface Form KRS

Dalam gambar 18 di atas, interface log in merupakan tampilan form persertujuan krs yang diambil untuk user yang telah melakukan $\log$ in ke dalam sistem. Isi dalam halaman menu ini adalah form pengambilan ambil krs yang dilakukan oleh mahasiwa. Tampilan yang ada merupakan total dari keseluruhan daftar mata kuliah yang akan diambil oleh mahasiswa. Semua data rersebut akan sesuai dengan semester yang diampuh oleh mahasiswa.

\section{PENUTUP}

Sesuai dengan hasil Analisis dan Perancangan Sistem Kartu Rencana Study (KRS) untuk Jurusan Teknik Informatika dan Sistem Informasi Kampus Tanri Abeng University yang telah diuraikan pada bab-bab sebelumnya, maka dapat disimpulkan bahwa sistem pengisian kartu rencana studi untuk jurusan Teknik Informatika dan Sistem Informasi yang dirancang dapat membantu proses pengumpulan data dan merekam data yang dilakukan oleh pihak akademik kampus Tanri Abeng University atas mata kuliah yang diambil oleh mahasiswa karena data sudah tersimpan disebuah database. Sistem pengisian kartu rencana studi secara online lebih baik dan efisien dari sistem sebelumnya, sehingga dapat melakukan penghematan baik dari segi waktu, biaya dan lain-lain.

Saran untuk penelitian selanjutnya agar sistem informasi yang telah dirancang dapat menjadi bahan masukan kedepan untuk pembuatan aplikasi dan dapat dikembangkan sesuai dengan kebutuhan yang ada.

\section{REFERENSI}

[1]. Jogiyanto. 2008. Metodologi Penelitian Sistem Informasi. Yogyakarta: Penerbit ANDI.

[2]. Kadir A, Triwahyuni TCH. 2003. Pengenalan Teknologi Informasi. Yogyakarta: Penerbit ANDI.

[3]. Munawar. 2005. Pemodelan Visual dengan UML. Yogyakarta: Graha Ilmu.

[4]. Netbeans.org. "Netbeans IDE". Diakses pada 17 April 2018

[5]. O'Brien, James A. 2005. Introduction to Information System, Twelfth Edition. Northen Arizona: Mc GrawHill.

[6]. Sugiri, H.S. 2008. Pengelolaan database MySql dengan PhpMyAdmin. Yogyakarta: Graha Ilmu.

[7]. Welling, Luke dan Thomson, Laura. 2001. PHP \& MySQL Web Development. ÛSA: Sams Publishing. 